\title{
Long-term diet-induced, tissue-specific changes in (non)adipose triglyceride stores in obese patients with type 2 diabetes mellitus
}

\author{
Jacqueline T Jonker, Marieke Snel, Sebastiaan Hammer, Arend E Meinders, Hanno Pijl, Ingrid M Jazet, \\ Johannes A Romijn, Johannes WA Smit, Albert de Roos, Hildo J Lamb
}

From 2011 SCMR/Euro CMR Joint Scientific Sessions

Nice, France. 3-6 February 2011

\section{Introduction}

A very low calorie diet (VLCD) induces considerable weight loss in patients with type 2 diabetes mellitus, associated with improved insulin sensitivity and decreased triglyceride (TG) stores in (non)adipose tissues. Long-term effects of a VLCD on tissue-specific TG accumulation, including pericardial fat, have not been documented.

\section{Purpose}

To assess the effects of a 16-week VLCD and of subsequent 14 months of follow-up on a regular diet on tissue-specific TG stores in obese type 2 diabetes patients.

\section{Methods}

We included 14 obese patients with insulin treated type 2 diabetes (mean \pm SEM: age $53 \pm 2$ years; BMI $35 \pm 1 \mathrm{~kg} /$ $\mathrm{m}^{2}$ ). (Non)adipose TG stores were measured using magnetic resonance (MR) imaging and MR proton spectroscopy before and after a 16-week VLCD (Modifast, 450 $\mathrm{kcal} /$ day) and after a 14-month follow-up without dietary interventions.

\section{Results}

A 16-week VLCD significantly reduced bodyweight, hepatic TG content, visceral and subcutaneous abdominal fat and pericardial fat volumes to 78, 16, 40, 55 and $83 \%$, respectively, of baseline values (all $\mathrm{p}<0.05$ ). After an additional 14 months of follow-up on a regular diet, weight and hepatic TG content increased significantly to 90 and $73 \%$ of baseline values $(\mathrm{P}<0.05)$. After these 14 months the preferential loss in visceral fat compared to

Leiden University Medical Center, Leiden, Netherlands subcutaneous abdominal fat was lost. In contrast, pericardial fat volume remained reduced to the same extent.

\section{Conclusions}

VLCD-induced weight loss and subsequent regain of weight during regular diet induces tissue-specific variations in (non)adipose TG stores in obese type 2 diabetes patients.

Published: 2 February 2011

doi:10.1186/1532-429X-13-S1-P352

Cite this article as: Jonker et al:: Long-term diet-induced, tissue-specific changes in (non)adipose triglyceride stores in obese patients with type 2 diabetes mellitus. Journal of Cardiovascular Magnetic Resonance 201113 (Suppl 1):P352.
Submit your next manuscript to BioMed Central and take full advantage of:

- Convenient online submission

- Thorough peer review

- No space constraints or color figure charges

- Immediate publication on acceptance

- Inclusion in PubMed, CAS, Scopus and Google Scholar

- Research which is freely available for redistribution

Submit your manuscript at www.biomedcentral.com/submit
() Biomed Central
(C) 2011 Jonker et al; licensee BioMed Central Ltd. This is an open access article distributed under the terms of the Creative Commons Attribution License (http://creativecommons.org/licenses/by/2.0), which permits unrestricted use, distribution, and reproduction in any medium, provided the original work is properly cited. 